This item was submitted to Loughborough's Research Repository by the author.

Items in Figshare are protected by copyright, with all rights reserved, unless otherwise indicated.

\title{
Exploring the attitudes, experiences and dynamics of interaction in online
} groups

PLEASE CITE THE PUBLISHED VERSION

PUBLISHER

(c) Elsevier

LICENCE

CC BY-NC-ND 4.0

REPOSITORY RECORD

Finegold, Adam R.D., and Louise Cooke. 2019. "Exploring the Attitudes, Experiences and Dynamics of Interaction in Online Groups". figshare. https://hdl.handle.net/2134/3279. 
This item was submitted to Loughborough's Institutional Repository by the author and is made available under the following Creative Commons Licence conditions.

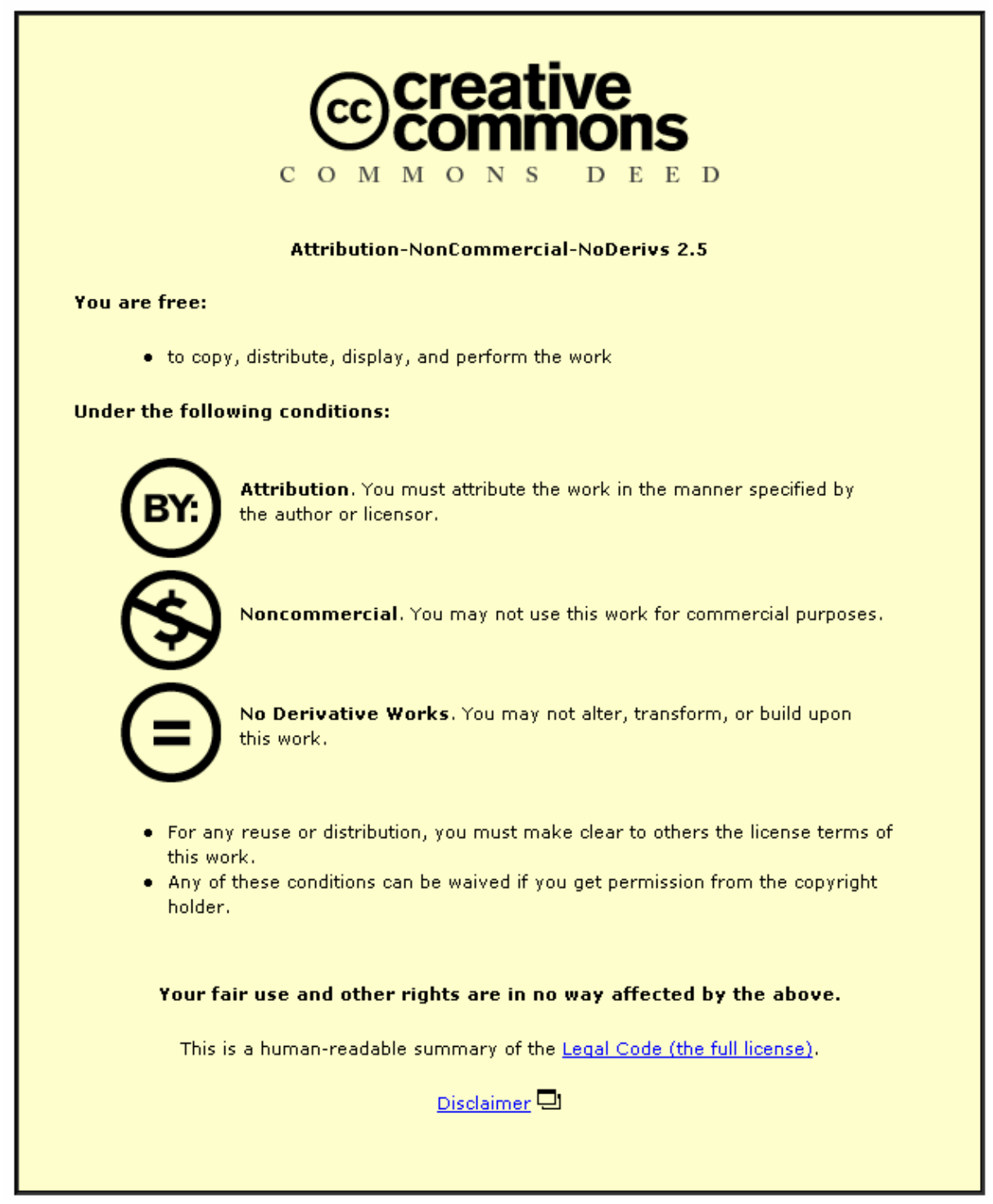

For the full text of this licence, please go to: http://creativecommons.org/licenses/by-nc-nd/2.5/ 


\title{
Exploring the attitudes, experiences and dynamics of
}

\section{interaction in online groups}

\author{
Adam R D Finegold a, Dr Louise Cooke b, \\ a Department of Information Science, City University, Northampton Square, London, EC1V 0HB \\ b Department of Information Science, Loughborough University, Loughborough, LE11 3TU \\ a Corresponding author/principal Investigator Adam.Finegold@hotmail.com \\ b L.Cooke@lboro.ac.uk / +44 (0) 1509228058
}

\begin{abstract}
The aim of this research was to improve understanding of the attitudes, experiences and dynamics of interaction of students working in online groups. This was achieved through a case study of postgraduate Information Studies students using the WebCT discussion board at City University in the academic year 2004-2005. Qualitative and quantitative methods were employed in combination including questionnaires, interviews, document analysis and discussion board analysis. The latter method involved adapting an existing content analysis framework. The findings highlight the significance of group member participation, collegiality and familiarity among group members. Students enjoyed working in online groups and found the discussion board useful, but often gave preference to other communication methods. Lecturer presence in online groups was found to be important to students, but interaction on the group discussion board was mostly student-centred. Provision of non-referential topic-related information, opinion and solidarity were the most common types of interaction.
\end{abstract}

Keywords: Collaborative learning; computer-mediated communication; higher education; content analysis; group work; e-learning 


\section{Introduction}

Higher education institutions are increasingly introducing courses partially or completely online in order to increase participation and social heterogeneity and to compete with other institutions (Palloff \& Pratt, 2001; Armitage \& O'Leary, 2003; Song, Singleton, Hill \& Koh, 2004). These courses are usually delivered through Virtual Learning Environments (VLE) incorporating computer-mediated communication technology, such as WebCT, and are seen as having the potential to improve student learning through providing access to resources and facilitating interaction and collaboration online (McConnell, 2000; Salmon, 2002b). However, although collaboration in face-to-face groups is considered constructive for learning, (Johnson \& Johnson, 1989; Laurillard, 2002) the implementation of learning technology in higher education institutions has shown comparative success online is not guaranteed (Delport \& de Villers, 2004). The dynamics, attitudes and experiences of online groups is less understood compared to face-to-face groups (McGrath \& Hollingshead, 1994; McConnell, 2000; Palloff \& Pratt, 2001; Salmon, 2002; Meyer, 2004). There is a need for further qualitative research investigating student perspectives on the importance, purpose, motivation, usefulness and challenges of using asynchronous discussion for group work (Hara \& Kling, 1999; Vonderwell, 2003; Song et al., 2004) and the experiences, processes and success factors involved in working in online groups (McConnell, 2000; Lock, 2002; Edrishingha, 2004). In addition, there is much scope to explore the dynamics of interaction in online groups through adapting existing frameworks which have been developed to understand face-to-face groups (Johnson, Suriya, Yoon, Berrett \& La Fleur, 2002; Meyer, 2004). Consequently, this case study provided the opportunity to improve current understanding of online group interaction and to test the usefulness in this context of a particular content analysis framework. 


\section{Background}

It has been argued that Computer Mediated Communication (CMC) technology provides students with the opportunity to collaborate and exchange ideas, experiences, opinions, interpretations and resources (Hiltz, 1998; Stacey, 1999; McConnell, 2000), to share workload (Bruhn-suhr \& Hamadeh, 2004) and ultimately to solve problems (Collins \& Berge, 1996). The potential for students to develop higher-level cognitive skills through online asynchronous collaboration, such as reflection (Hara, Bonk \& Angeli, 1998; Ellis, 2001; Salmon, 2002b), elaboration and clarification (Pena-Shaff \& Nicholls, 2004) has also been emphasised. According to John Seeley Brown, (in Schrage, 2002) this ability to "link, lurk and learn” amounts to "the most successful form of learning that civilization has ever seen.”

Indeed, much research has focused on the benefits and effectiveness of online education, often in comparison with the traditional face-to-face mode of study (Warkentin, Sayeed \& Hightower, 1997 1997; Hiltz, 1998). Most early research was particularly optimistic (Hiltz in Burge, 1993) and this initial hype has since been criticised for taking a biased view of technology and exaggerating its potential to improve learning (Hara \& Kling, 1999). In light of more recent studies identifying negative student and lecturer experiences with online technology, Jones and Steeples (2002) argue that "the idea that the technology either requires collaboration or is especially fitted to collaborative activity appears to be an unwarranted determinist assertion.” This is supported by Armitage and O’leary (2003) and Kreijns and others (2003) who clarify that technology only provides the platform for group interaction and Laurillard (2002) who argues that the "properties of the medium....do not determine the quality of the learning that takes place.” Accordingly, there has been much research addressing factors that lead to successful group outcomes.

Asynchronous discussion board messages have provided researchers with the opportunity to analyse 
interaction and learning. Structural analysis entails measurements of participation levels and interaction patterns between participants. For example, Masters and Oberprieler (2004) have measured the number and length of discussion messages of undergraduate students using WebCT in order to test whether participation could be encouraged without awarding grades. However, a key limitation of all structural analysis studies is that they do not indicate the quality of interaction or learning occurring in the discussions (Drops, 2003; Vonderwell, 2003). Consequently, research has been undertaken using hierarchical content analysis frameworks, whereby discussion text is systematically coded in order to achieve a better understanding of online interaction. (Hara et al., 1998; Pena-Shaff \& Nicholls, 2004; Busch, De Maret, Flynn, Kellum, Le, Meyers, Aunders, White \& Palmquist, 2005). Meyer (2004) measured the level of thinking and intellectual and ethical development of students through four different content analysis frameworks (King \& Kitchener, Garrison, Perry, Bloom in Meyer, 2004). These frameworks were found to be useful in measuring student learning processes, although it was stressed that more research is needed to understand how “a group conversing online works as a group, how it works together to develop an understanding of and solutions to a problem.” (Meyer 2004).

There has been research pertaining to the attitudes and experiences of students and lecturers in higher education towards the positive and negative aspects of working online and perceived strengths and weaknesses of using asynchronous discussion for learning. Burge (1993) studied two small groups of part-time students on two Masters of Education distance courses to address how asynchronous discussion was perceived. Access to peer knowledge, availability of students to provide feedback, ability to access the technology at their convenience and opportunity to reflect on messages were identified as positive aspects of using the technology for learning. The latter two strengths were also identified by students in Ellis’ (2001) study of groups using a VLE to supplement face-to-face lectures, whilst in research by Stacey (1999) and Vonderwell (2003) students perceived asynchronous discussion useful for constructing and sharing knowledge in 
groups.

In terms of difficulties experienced, the students in Burge’s (1993) study cited information overload, technological problems and absence of timely feedback and of visual clues, particularly in collaborative work. Similarly, misinterpretation through lack of non-verbal cues was found by Lopez-Ortiz and Lin (2005) whilst student frustration with technological issues and lack of feedback was found by Hara and Kling (1999 and 2000) in their ethnographic study of distance learning students. Edirisingha (2004) examined the attitudes of thirty students to the integration of asynchronous discussion in their learning at a university using a VLE to supplement face-to-face study. Students who did not use the discussion facility cited anxiety over posting messages, technological problems and a preference for different communication methods, noting that ample opportunity for interaction with students and lecturers face-to-face rendered online interaction less necessary (Edirisingha, 2004). In contrast, Qunisee’s (2002) study of postgraduate students found face-to-face contact did not affect discussion board usage, although this was not within a group setting and was based on discussion board analysis and not student perceptions. Student concerns regarding the participation of other online group members, (Vonderwell, 2003) the quality of online discussion (Ellis, 2001) and the time commitments needed to work online (Mason \& Miller, 2000; Gabriel, 2004; Song et al., 2004) have been cited in other studies.

\subsection{Scope and Coverage}

The research was conducted between July and September 2005 and was based on postgraduate students studying Information Science and Library and Information Studies at City university. The Information Studies department running these courses has been using WebCT to support distance students and supplement face-to-face teaching since September 2000. The first use of WebCT for group work occurred in the same year. A 'group’ refers to students and their respective lecturer 
placed in a designated area within the main asynchronous discussion board of WebCT. This is regardless of how often these students used the discussion board, the purpose of collaboration or whether students were self-selected. These students and the module lecturer are subsequently labelled 'group members'. All 105 students included in this case study will have been involved in group work and used WebCT to some extent during their studies at City University.

This case study was based on four compulsory modules and one elective module. They are Information Studies, Information and Library Management, Information Resources and Organisation, Retrieval Systems and Libraries and Publishing in the Information Society. These modules were chosen as they were the only modules taken by both Information Science and Library and Information Studies students and which used group discussion areas. Each module had a different lecturer and will have contained full-time and part-time students.

The research questions that guided the case study were derived from the literature analysis, and focused on the following areas:

- What were the attitudes towards, and experiences of, students working in online groups?

This question involved investigating whether students enjoyed working in online groups, and what concerns did they have about doing so? What were their perceptions of the purpose of the asynchronous discussion board in group work, and what motivated them to make use of the technology? What were the key benefits and challenges of using the group discussion board, and did they find it useful in facilitating their group work? How important was it for them to meet faceto-face? How did they go about the process of conducting group work online, and what factors helped them to make a success of the challenge? Finally, what role did their lecturer play in the process? 
- What were the characteristics of group dynamics that could be discerned in students working in online groups?

This question investigated the patterns and quality of interaction within online groups through a structural and content analysis of the asynchronous discussion board.

\section{Methodology}

The attitudes, experiences and dynamics of interaction in online groups were explored through both qualitative and quantitative research methods. The perspectives of students were gathered through questionnaires, interviews and analysis of documents. Dynamics of interaction and other themes pertaining to groups working online were explored through analysis of the structure and content of discussion board messages.

The principal investigator, as a student on the Information Science course at City University at the time of the research, will have experienced online group work and formed attitudes towards working in online groups. Thus, the potential for bias in interpreting research based on preconceived values, ideas or expectations is acknowledged. However, many “insider” studies have been successfully conducted by staff involved with online learning in higher education institutions (e.g. Quinsee, 2002; Salmon, 2003) and as a student, the researcher may have achieved a better understanding of contextual issues of the case study. Particular caution was exercised to remain objective at every stage of the research. The case study approach facilitates the opportunity to study relationships, experiences and processes of a particular phenomenon in depth, in context and within a short time period (Yin, 1994) However, it is additionally recognised that a single case study, whilst being useful in its ability "to illuminate the general by looking at the particular" 
(Denscombe, 2003, p.30), does not necessarily permit generalisation across the population. It is possible, for example, that Information Studies students are more receptive to the use of online tools than may be the case in some other discipline areas.

\subsection{Attitudes and experiences of students working in online groups}

3.1.1. Questionnaires. The questionnaire was designed to be completed anonymously online through an HTML form. Questionnaire categories were based on findings identified in the literature review and suggestions made following a pilot questionnaire. Students were provided with definitions of terms used in the questionnaire and a reminder of the modules involving group work. 23 students completed the questionnaires in total. Closed questions were analysed at nominal, ordinal or interval levels according to the type of question and open questions were analysed by grouping together common answers.

3.1.2. Interviews. The interviews explored the attitudes and experiences of students in greater depth than the questionnaire with more focus on the processes and strategies of online groups. Purposive sampling was used to select interviewees in order to gather a range of differing opinion. Two full-time students and two part-time students were selected from the eight students who volunteered through the questionnaire. Interviews were on a one-to-one basis and issues were covered through pre-prepared, open-ended questions used to initiate and sustain discussion.

Interviews with the full-time students were conducted face-to-face and recorded using a taperecorder. Interviews with the part-time students were conducted on the telephone and were recorded using dedicated computer software (USD, 2004). The recordings were carried out with the interviewees’ permission. The interview data, once fully transcribed, was coded to identify categories. 
3.1.3. Document analysis and voluntary comments. Feedback on group processes was gathered from five consenting students on the Libraries and Publishing in the Information Society module. Twenty students were enrolled on the module in total and each group contained four self-selected members. The feedback was part of a module coursework assignment asking students to reflect on the process of preparing a group presentation, including any team-working or communication issues encountered and addressed. The feedback was in the form of written documents and, in accordance with the terms of the consent request, were collated and anonymised by the module lecturer before being sent to the researcher.

Further comments regarding the attitudes and experiences of using asynchronous discussion for online group work were encouraged through a posting on a student WebCT discussion board. Two students sent comments to the researcher through the discussion board and four students sent their comments through e-mail. The voluntary comments were combined with the interview and group feedback data for qualitative analysis, thus providing triangulation of the research findings.

\subsection{Dynamics of group interaction}

The structural and content analysis was based on groups in the four compulsory modules. In one module, the groups were established to facilitate assessed collaborative assignments and group members were self-selected. In all other modules group tasks were not assessed and group members were imposed upon the student body by the lecturer. From each of the four modules, one group was randomly selected from the consenting groups and these four groups were used for both the structural and content analysis. The one condition held was that the groups could not contain the researcher as a member in order to reduce of the potential for personal bias. 
3.2.1. Structural analysis. This focussed on measuring patterns of interaction and participation as follows:

Participation:

- Proportion of messages by each group member (including lecturer if present): - This was calculated by counting the number of discussion posts contributed by each member and then calculating each members' postings as a percentage of the whole group.

- Number of group members not contributing: This was calculated by counting how many members assigned to the group did not post a message.

Relative interaction between full-time and part-time students:

- Average number of messages contributed by part-time students relative to full-time students: This measurement compared [the total number of contributions by part-time students divided by the total number of part-time students] against [the total number of contributions by full-time students divided by the total number of full-time students.]

Participation and frequent interaction are regarded by many researchers as fundamental to effective online learning (Hiltz, 1998; Lenning \& Ebbers, 1999; Chou, 2002; Lock, 2002; Gabriel, 2004). Accordingly, the interaction of the least and most active group members were subject to closer analysis within the content analysis of this case study. The students contributing the fewest and most messages were chosen as the least and most active students respectively in each group. The least active student had to post more than one message.

3.2.2. Content analysis. The content analysis framework used in this study was based on Bales' (1950) Interaction Process Analysis (IPA) framework which was originally used to measure the quantity and nature of interactions between members of small face-to-face groups. (See Figure 1). 
This framework is useful for revealing group behaviour, member roles and interaction patterns, particularly the social-emotional and task-orientated functions. Group activity that can be identified through the framework include communication, evaluation, control, decision-making, tension reduction and reintegration. In Bales’ IPA, group behaviour is classified into 12 categories. Categories 1-3 deal with positive social-emotional behaviour. This includes solidarity, tension release and agreement. In direct contrast, categories 10-12 deal with negative social-emotional behaviour; antagonism, tension and disagreement. According to Bales, social-emotional interaction is necessary to mediate task-related interaction. Categories 4 to 9 deal with task-orientated behaviour. These categories are divided into attempted answers and questions which are each further subdivided into suggestions, opinions and orientation.

Alterations were made to Bales’ IPA framework by the researcher in order that analysis was appropriate for the online environment and to provide additional insight into group interaction. Existing and created categories are mutually exclusive and exhaustive (Stemler, 2001). Firstly, all changes made by Chou (2002) were adopted in this case study. Chou (2002) found that online interaction necessitated the expansion of categories 6 and 7 to include giving and asking personal, topic-related and technical information respectively. Further alterations involved adding categories from Fahy’s (2003) Transcript Analysis Tool. Specifically, categories 2A and 2B were included under categories 6.2 and 7.2 in the modified Bales’ IPA framework. (See Table 1) This addition was in order to explore the extent to which discussion occurs through building on previous information from other group members. This form of interactivity is also tested in Salmon's (2002) conference analysis framework as “critiquing, challenging, discussing and expanding ideas of others.” The limitation of this is that the referrals to other group members in the form of suggestions or opinions were not recorded by this framework. Similarly, categories 5 and 8 were subdivided to make a distinction between evaluation, analysis, peer review $(5.1,8.1)$ and opinion, feeling, wish (5.2, 8.2). The former is asking for or giving analysis of documents submitted to the discussion 
board, as well as documents sent among group members through e-mail. The latter are opinions or expressions of feelings regarding any matter other than that which falls into categories 5.1 and 8.1. Finally, categories 4 and 9 were expanded to explore the quantity of suggestions pertaining to organisation of the group $(4.1,9.1)$ and the quantity of suggestions pertaining to the details of the task (4.2, 9.2). This alteration attempted to provide further understanding of how asynchronous discussion is used in group work. Organisation suggestions referred to roles, labour division, meeting times, meeting locations, organisation of discussion threads and deadline suggestions. After coding the first 30 messages of the first group, no further alterations to the framework were considered necessary.

\section{[INSERT TABLE 1]}

The unit of analysis for coding was a sentence. All sentences of all messages of each sample group were read and assigned a category number from the framework. This included documents containing text that were attached as a file within a discussion message. However, sentences containing a subordinate conjunction (i.e. 'but', 'although', 'because', 'as' ) were consistently categorised in parts to improve the accuracy of the analysis. A block of data copied verbatim from a book or software system was categorised as one unit to maintain consistency. Where more than one category could be assigned to a sentence, the most appropriate category was inferred from the surrounding sentences. Sentences categorised within a sub-division of the framework were additionally assigned a category number from its parent categories. For example, a sentence which gave referential topic-related information was assigned the category 6.22, as well as, 6.2 and 6 . Whether the sentence was contributed by a lecturer or student was also recorded. All four groups were re-categorised by the researcher five days after the first categorisation to test coding reliability. However, a margin of error should be accepted as part of this content analysis. 
Analysis was conducted using data from the second categorisation. The proportion of each message category was calculated and contrasted in each group to reveal how the asynchronous discussion board was used and the type and degree of interaction taking place. Several questions, based on the overall research questions, guided the content exploration. These included:

- What is the balance between social-emotional behaviour and task-oriented behaviour?

- What is the balance between questions asked and answers provided?

- How different are the online group dynamics between students and lecturers?

- How different are the online group dynamics between the least active and most active students?

- What was the most frequently coded category?

- To what extent did discussion occur through building on previous information from other group members?

- To what extent did peer review occur?

- To what extent is the discussion board used for task and organisational suggestions?

To supplement the categorisation, any issues raised within the content of group messages pertaining to the strengths and challenges of conducting group work using the discussion board, the role of the lecturer and the process of conducting group work online were extracted in the form of quotes. These were used to provide further triangulation with the attitudes and experiences expressed in the interviews, questionnaires, group feedback and voluntary comments, as well as, the dynamics of interaction explored through discussion board analysis.

Bales’ IPA cannot measure group members' impressions of each other (Hartley, 1997) and did not take account of interaction occurring face-to-face and through other online technology, such as email and synchronous CMC. However, interaction and perspectives pertaining to other media were 
addressed through student interviews. The content analysis framework employed is likely to oversimplify the complex nature of interaction (Busch et al., 2005) and the lack of contextual clues may have increased the possibility of coding inaccuracy, for example when inferring socio-emotive communication. Despite these limitations, content analysis can offer a valuable method of understanding group dynamics (Stemler, 2001).

3.3. Ethical considerations. Informed consent was obtained from students and lecturers before use of the discussion messages and group process feedback. All participants involved in this study are reported anonymously; questionnaire respondents did not have to supply their name even if they volunteered for interviews and pseudonyms were used for the four interview participants. Transcripts and interview recordings were destroyed after the research. These considerations were made explicit to those involved in the case study.

\section{Results and Discussion}

Most students conveyed working in online groups as a positive experience. They particularly enjoyed learning, sharing and bonding with other group members and working towards a common objective. Some students preferred not to work in groups if given the choice, citing difficulties related to the nature of group work and not the discussion board specifically.

The findings of this study support a number of themes discussed in the existing literature on online learning, as indicated by the use of parentheses. Group members not participating on the discussion board and not contributing equally towards the completion of group tasks were the most prominent concerns experienced by students working in online groups (Vonderwell, 2003; Jones, Asensio, Goodyear, Hodgson \& Steeples, 2001). Active participation was also regarded by students as the most important factor influencing the success of online groups (Chou, 2002; Gabriel, 2004). Where participation was not forthcoming, some students experienced frustration at having to take on extra 
workload, and anxiety in trying to persuade the non-participating group members to contribute. Thus, most students did not find the discussion board itself was enough to ensure collaboration in groups (Hiltz, 1998; Laurillard, 2002; Kreijns, Kirschner \& Jochems, 2003). Interestingly, some full-time students felt part-time students contributed less to group work and could not be relied upon because of their work commitments. Indeed, finding time to regularly contribute towards group work and discussions taking place on the discussion board was raised as an issue by many part-time students. Analysis of the discussion board indicated that full-time students tended to post more messages than part-time students. However, students additionally identified lack of enthusiasm to use technology, differences over the actual task and that preference was given to assessed coursework to explain the non-collaboration in online groups.

Most students found the discussion board useful for group work, particularly when they could not meet face-to-face and placed greater emphasis on its benefits than its challenges. Benefits experienced by the most students were the ability to share ideas, experiences and resources (Burge, 1993; Stacey, 1999; Vonderwell, 2003) and the ability to conduct group work despite physical separation (Hightower \& Sayeed, 1996; Lopez-Ortiz \& Lin, 2005). Flexibility and convenience (Burge, 1993; Picciano, 1998; Ellis, 2001) were cited in comparison with working face-to-face. Some thought the discussion board had improved their learning due to the ability to reflect on messages (Burge, 1993; Hara et al., 1998; Ellis, 2001) and had advanced their communication skills (Vonderwell, 2003).

However, it is clear that not all students used the discussion board for group work in all modules. Most students felt the need to meet face-to-face during group work and some students chose to conduct group work using e-mail. The reasons provided by students are important in highlighting the limitations of the discussion board for group work. Students felt that bonding with group members and trying to explain complex ideas was easier face-to-face, mostly due to time-delays 
before replies and the potential for misunderstanding. Some students found the discussion board to be impersonal and intimidating, attested in part by the lack of personal details exchanged on the discussion board. Face-to-face meetings were perceived as particularly useful at the beginning of group tasks to make initial task decisions and towards the end to compile work for submission or to rehearse the group presentation. Sending large attachments was considered by some students as easier through e-mail, and other students felt more comfortable using e-mail to discuss problems in confidence. Indeed, some students only used the discussion board to post their final document if required by the group task. Preference for different communication methods has also been found by Jones et al (2001), Gabriel (2004), Lopez-Ortiz and Lin (2005) and Edirisingha (2004) and in support of the latter study, this case study found that some students were less likely to use the discussion board if the whole group could meet face-to-face. Overall, the discussion board was seen as a viable alternative to face-to-face meetings and the most convenient way of contacting group members, but most preferred having the option to use the discussion board, e-mail and face-to-face meetings in order to complete the group tasks. The findings suggest that lecturers should not force students to use the discussion board for group work where viable alternatives exist, and that clarification should be communicated regarding whether use of the discussion board is compulsory in order to demonstrate progress.

Students thought discussion was easier on the group discussion board than the general discussion area of each module and recognised the value of having 'conversations' recorded for future reference and reflection. In support of earlier research at City University by Boutrin (2003), students did feel it was easier to discuss issues in smaller groups of three or four students. Smaller groups were also thought to facilitate equal participation on the discussion board and were considered important for the success of online groups. The results additionally highlight the importance attributed by students to being familiar with other group members in order to communicate effectively and reduce misunderstanding on the discussion board. Students felt it was 
more important to be familiar with group members than to work face-to-face and it was better to like group members than to be familiar with them. This clarifies research by Robey, Khoo and Powers (2000 in Gabriel, 2004) who argue that groups work more effectively when they have met face-to-face.

The emphasis given to challenges experienced in using the discussion board for group work varied among students and some indicated that they experienced no challenges at all. Time delays before replies of both students and lecturers (Hara \& Kling, 1999; Mason \& Miller, 2000; Vonderwell, 2003) was the most commonly cited challenge and was thought to slow down group progress, causing misunderstanding and missed opportunities. Many students also reported experiencing anxiety over posting messages (Picciano, 1998; Edirishingha, 2004) and misunderstanding due to lack of visual cues (Burge, 1993; McGrath \& Hollingshead, 1994; Lopez-Ortiz \& Lin, 2005). The emphasis attributed to challenges differs from previous studies at City University where information overload (Bullimore, 2002; Boutrin, 2003) was identified as the most prominent challenge, albeit not within a group context. The latter challenge was however also identified in this case study and some students linked information overload (Burge, 1993; Gabriel, 2004) with technological limitations of the discussion board in that deleting, updating, organising and searching through messages was not possible. Technological problems (Hara \& Kling, 1999; Hara \& Kling, 2000; Edirishingha, 2004; Song et al., 2004) additionally prevented some students from accessing and using the discussion board and this was often reported on the discussion board.

The findings of this case study show that challenges experienced were often interrelated, but also suggest that students were able to overcome many barriers to progress if certain success factors were present. For many students, these success factors included an atmosphere of trust and respect, shared objectives (Wenger, 1999) and being supportive to other group members (McConnell, 2000; Palloff \& Pratt, 2001). These can be considered elements constituting a learning community and 
seemed to increase student motivation to participate. Group working skills, such as decisionmaking, consensus building, (Gabriel, 2004) and dealing with conflict (McGrath \& Hollingshead, 1994; McClure, 1998) were also strongly factored by many students. However, students also recognised that group member confidence in using the discussion board and the technical functioning of the discussion board were prerequisite conditions for interaction (Song et al., 2004). Similarly, the nature of the group task seemed to influence how motivated students were to participate, the amount of academic discussion on the discussion board and whether participating students collaborated or cooperated. . The definitions of Roschelle and Teasley (in Lehtinen et al, 1997) were used to distinguish between collaborative and co-operative work.

Lecturer presence in online groups was seen as important by most students and perspectives regarding the role of lecturers were elicited through the results. Many students thought lecturers should monitor and contribute to the discussion board and provide motivation, and that this should occur both online and face-to-face. However, attitudes varied with regard to the type of input and form of encouragement students felt lecturers should provide. Most students thought lecturers should intervene in online groups to clarify coursework requirements and emphasised the importance of clear instructions regarding the group task. This supports research by Hara and Kling (2000), Jones et al (2001) and Vonderwell (2003). Salmon (2003) and Delport and de Villers (2004) highlight the importance of lecturer feedback and in this study many students felt that lecturers should provide clarification on progress and correct inaccurate student contributions. Direction in the form of information resources, subject knowledge and discussion initiation was thought to be helpful and some students thought lecturers should also address problems with technology, encourage those not participating on the discussion board and mediate disagreements on the discussion board. It seems that these circumstances of intervention may be important for the success of online groups given that concerns of isolation, conflict on the discussion board and the quality of discussion on the discussion board were experienced by at least one student to a very great extent. 
However, only a few students felt lecturers should allocate group roles and responsibilities and some students commented that lecturers should not dominate discussions or censor material. The findings suggest that most students perceived learning in online groups as a constructivist process whereby they were responsible for actively creating knowledge from prior knowledge instead of being passive consumers of objective information from lecturers (Armitage \& O'Leary, 2003).

Analysis of the group discussion boards found that lecturers variably contributed encouragement, (category 1) opinion, (category 5) topic-related information (category 6) and to a lesser extent, agreement (category 3), task suggestions (category 4) and requests for topic-related information (category 7). There is also evidence that lecturers posted topic-related information in reference to other group members statements (sub-category 6.22) and provided analysis on documents submitted to the discussion board. Thus, student attitudes towards the role of lecturers in online groups reasonably reflected interaction on the discussion board (sub-category 7.1). However, some students felt that the lecturer input did not make a difference to the group due to the peer interaction already taking place. Indeed, all types of interaction contributed by lecturers on the discussion board were also contributed by students, some groups interacted and completed group tasks without any lecturer input on the discussion board and students provided more units than lecturers in all groups analysed. Students additionally stated that student feedback on the discussion board during group work was more important than lecturer feedback. The findings suggest that interaction on the discussion board was largely student-centred and in contrast to findings by Ellis (2001), this was the case even when the lecturer posted messages on the discussion board. (See tables 2 and 3.)

Interestingly, the results indicate that collegiality was important to students working in online groups. Most students stated that there was no established hierarchy in their online groups, roles were assumed and not assigned and that they did not have a leader. In addition, some students thought an online leader would be beneficial if they ensured equality, but not if they dominated the 
group output, whilst other students experienced dominating learners as a concern on the discussion board. Emphasising the importance of both participation and collegiality was the finding that many students felt motivated to use the discussion board in order to demonstrate progress to each other and the lecturer. The significance attributed by students to equal participation online supports research by Ellis (2001), but the findings do not indicate whether the discussion board facilitated greater equality of participation and less hierarchy than groups working face-to-face as found by Hiltz and Turoff (1993) and McConnell (2000) respectively. Another interesting finding was that most students did not establish any ground rules on how, when or how often they were going to use the technology for group work. Students usually assumed group members would view the group discussion board regularly and did not always experience the feeling of security through expectations on how to contribute. This supports research by McConnell (2000) and Gabriel (2004) who argue that groups need to negotiate the rate of online participation.

The discussion board analysis suggests that group members tried to perform their task and maintain the group's stability on the discussion board (Pavitt, 1998) with information provision (category 6) and solidarity (category 1) among the most common types of interaction in all groups analysed. However, although found to be important by Northrup (2001), Kreijns et al (2003) and Vonderwell (2003), social interaction was considered less significant than other success factors in this case study and there was less social-emotional interaction (categories 1-3 and 10-12) on the discussion board than task-orientated interaction (categories 4-6 and 7-9) in all groups. Hara et al (1998) also found that students exchanged mostly task-focused messages when using asynchronous CMC for group work.

More task-orientated answers (categories 4-6) were provided than questions asked (categories 7-9) and provision of topic-related information (sub-category 6.2) was the most common type of 
interaction. Provision of opinion and expression of feeling (category 5) was also very common in the groups analysed and students felt the freedom to express their own independent thoughts, at least to some extent. However, most topic-related information posted was not in reference to the statements of other group members (sub-category 6.21) and in only one of the groups analysed was peer review or analysis (sub-category 5.1) provided on the discussion board. This is despite student feedback being cited by students as one of the benefits of using the discussion board for group work and important for the success of online group projects. That students tended to post their individual research without interacting with other group members has also been found by Chou (2002). Requesting opinion or analysis (category 8) was among the least common types of interaction on the group discussion board and given that anxiety over posting messages was a challenge experienced by students and that more agreement (category 3) occurred than disagreement (category 10), it may have been easier for some group members to provide and process information than to provide or receive criticism.

[INSERT TABLES $2+3]$

A summary of the findings can be found in Table 2.

[INSERT TABLE 4]

\section{Conclusion}

\subsection{Reflections on methodology}

Problems were experienced obtaining the consent needed from students to carry out the discussion board analysis. Some students were difficult to contact and others declined to participate and this limited the number of groups that could be randomly selected from each module. Furthermore, only 
assumptions could be made in this case study regarding why certain students in online groups did not use the discussion board. It may have been beneficial to provide questionnaire respondents with an open-ended area to describe their experience with regard to this issue.

As this research was conducted after online group work had finished, other methods that may have been appropriate to fulfil the research aim could not be employed. Diaries may have been useful to gather information on the work patterns of students in online groups. Direct observation, may have been useful to understand interaction occurring in face-to-face groups or the face-to-face meetings of online groups (Hiltz \& Turoff, 1993). However, the fact that analysis was conducted after the course was completed enabled a fuller picture to be evaluated and, despite the problems and limitations highlighted, the methodology can be considered successful in gathering reliable and valid data which could be triangulated to understand the attitudes, experiences and dynamics of interaction of students working in online groups. This case study has also successfully developed, tested and found useful a framework for evaluating interaction in online groups which may be used or adapted for analysis of asynchronous CMC boards in future research.

\subsection{Recommendations for further research}

Many of the findings of this study warrant further exploration to provide a more comprehensive understanding of online groups. As the contribution of part-time students was raised as an issue by some full-time students, the work patterns of part-time students could be investigated through the use of diaries. To achieve a more complete picture it may additionally be useful to investigate the attitudes of lecturers towards the purpose of the discussion board in group work, whether they experience the same challenges as students and how they perceive their role.

With regard to the dynamics of interaction in online groups, this case study has only evaluated the group discussion messages of four groups. With consent, a larger content analysis may be 
conducted to explore whether interaction patterns highlighted in this study can be identified or clarified. For example;

- Do full-time students always post more messages than part-time students and are the latter always the least active students?

- Do lecturers post any other types of interaction?

- Do groups with full-participation on the discussion board provide more analysis, peer review and evaluation on the discussion board?

Further studies may be contextualised in reference to learner achievement, learning and teaching styles, cost effectiveness, course design and the technology itself. These areas were not explored in depth within this case study.

This paper identified face-to-face meetings and e-mail as important for many students and future research could explore the level and type of interaction taking place through these mediums. Furthermore, one of the limitations of the content analysis was that it did not measure changes in interaction over time. Thus, to gain a better understanding of online group development, frameworks such as McClure’s (in Palloff \& Pratt, 2001) group development model could be employed. Analysis could also be undertaken to better understand the effect of time delays and group size on student interaction on the discussion board. For example, average full-time student response times may be measured for each category of the Modified Bales IPA and compared with that of part-time students and lecturers. Finally, the adapted framework used in this case study may be tested on groups within a different setting. 


\subsection{Summary}

Overall, this case study is both exploratory and evaluative. The research indicates that online group discussion boards offer a useful platform for student interaction, facilitating the completion of group work tasks. However, it suggests that students also experience a number of challenges in using online asynchronous communication for such work and value the opportunity for interaction through other mediums. Barriers to progress could be overcome if certain success factors were present and the findings highlight the significance of group member participation, collegiality and familiarity among group members. Lecturer presence in online groups was found to be important to students, but interaction on the group discussion board was mostly student-centred. Provision of non-referential topic-related information, opinion and solidarity were the most common types of interaction. Lecturers and course designers may adjust strategies and approaches in light of issues highlighted in order to employ technology in the most effective way, to deal with problematic areas and improve student learning experiences.

\section{References}

Armitage, S. \& O'Leary, R. (2003). e-Learning Series No. 4: A Guide for Learning Technologists. York. Learning and Teaching Support Network.

Bales, R. (1950). Interaction process analysis: a method for the study of small groups. Chicago: University of Chicago Press.

Bruhn-suhr, M. \& Hamadeh, J. (2004). The makes and brakes of collaborative learning in an elearning environment, 10th International Conference on Technology Supported Learning and training, Online Educa Berlin, 94-97. 
Boutrin, M. (2003). E-learning is all dialogue, involvement, support and control: An evaluation of online learning in higher education examining interaction with content and interaction with other people, V-lib Library Electronic Papers, City University. Retrieved April 30, 2005, from http://vlib.city.ac.uk/

Bullimore, A. (2002). Identification and Evaluation of Online Learning Communities: An Exploration of a Case Study of Postgraduate Face-to-Face Students Using a Managed Learning Environment, V-lib Library Electronic Papers, City University. Retrieved April, 30, 2005, from http://vlib.city.ac.uk/

Burge, E. (1993). Students’ perceptions of learning in computer conferencing: A qualitative analysis. Unpublished doctoral thesis, University of Toronto. Retrieved May 18, 2005, from http://www.lib.unb.ca/Texts/EducationReserves/Burge.html

Busch, C., De Maret, P., Flynn, T., Kellum, R., Le, S., Meyers, B., Aunders, M., White, T. \& Palmquist, M. (2005). Overview: Content Analysis, Colorado State University. Retrieved May 29, 2005 from http://writing.colostate.edu/references/research/content/com2d2.cfm

Chou, C. (2002). A Comparative Content Analysis of Student Interaction in Synchronous and Asynchronous Learning Networks, Proceedings of the 35th Hawaii International Conference on System Sciences. Retrieved May 2, 2005, from http://csdl.computer.org/comp/proceedings/hicss/2002/1435/05/14350134b.pdf

Collins, M. \& Berge, Z. (1996). Facilitating Interaction in Computer Mediated Online Courses, FSU/AECT Distance Education Conference, Tallahassee. Retrieved May 3, 2005, from http://victorian.fortunecity.com/vangogh/555/dist-ed/roles.html

Delport, R. \& De Villers, C. (2004). Determinants and effects of CMC in Information Science, Learning, 10th International Conference on Technology Supported Learning and training, Online Educa Berlin, 97-99.

Denscombe, M. (2003). The Good Research Guide for small-scale research projects, (2 ${ }^{\text {nd }}$ ed.). Philadelphia: Open University Press. 
Drops, G. (2003). Assessing Online Chat Sessions. Retrieved June 6, 2005, from https://www.ucalgary.ca/ commons/oc/0304OC.pdf

Edirisingha, P. (2004). Discussing to Learn - How undergraduates integrate online discussion forums in their learning activities, ALT-C 2004: $11^{\text {th }}$ International conference Research Proceedings, Hull, 11-123.

Ellis, A. (2001). Student-centred collaborative learning via face-to-face and asynchronous online communication: what's the difference? Proceedings of the 18th Annual Conference of the Australian Society for Computers in Learning in Tertiary Education, Melbourne, 169177 .

Fahy, P. (2003). Indicators of Support in Online Interaction, International Review of Research in Open and Distance Learning. Retrieved May 5, 2005, from http://www.irrodl.org/content/v4.1/fahy.html

Gabriel, M. (2004). Learning Together: Exploring Group Interactions Online, Journal of distance education, 19(1), 54-72.

Gerbic, P. \& Stacey, E. (2005). A purposive approach to content analysis: Designing analytical frameworks, Internet and Higher Education, 8, 45-59.

Hara, N., Bonk, J. \& Angeli, C. (1998) Content Analysis of Online Discussion in an Applied Educational Psychology, Center for Research on Learning and Technology, Indiana University. Retrieved May 30, 2005, from http://crlt.indiana.edu/publications/journals/techreport.pdf

Hara, N. \& Kling, R. (1999). Students' Frustrations with a Web-Based Distance Education Course, First Monday, 4(12). Retrieved May 18, 2005, from http://www.firstmonday.dk/issues/issue4_12/hara/index.html

Hara, N. \& Kling, R. (2000). Students’ Distress with a Web-based Distance Education Course: An Ethnographic Study of Participants' Experiences, Center for Social Informatics. Retrieved May 18, 2005, from http://www.slis.indiana.edu/CSI/WP/wp00-01B.html 
Hartley, P. (1997). Group Communication. London: Routledge.

Hiltz, S. \& Turoff, M. (1993). The Network Nation: Human Communication via Computer. Massachusetts: The MIT Press.

Hiltz, S. (1998). Collaborative Learning in Asynchronous Learning Network: Building Learning Communities, WEB98, Florida. Retrieved May 17, 2005, from http://eies.njit.edu/ hiltz/collaborative_learning_in_asynch.htm

Hightower, R. \& Sayeed, L. (1996). Effects of communication mode and pre-discussion information distribution characteristics on information exchange in groups, Information Systems Research, 7(4), 451-465.

Johnson, D. \& Johnson, R. (1989). Cooperation and competition: Theory and research. Edina, MN: Interaction Book Company.

Johnson, S., Suriya, C., Yoon, S., Berrett, J. \& La Fleur, J. (2002). Team development and group processes of virtual learning teams, Computers \& Education, 39(4), 379-393.

Jones, C., Asensio, M., Goodyear, G., Hodgson, V. \& Steeples, C. (2001). Final Report on the Field Studies: Networked Learning in Higher Education Project, The Centre for Studies in Advanced Learning Technologies, Lancaster University. Retrieved May 6, 2005, from http://csalt.lancs.ac.uk/jisc/guidelines.htm

Jones, C. \& Steeples, C. (2002). Perspectives and Issues in Networked Learning. In: Steeples, C. and Jones, C. (Eds.) Networked Learning: Perspectives and Issues. London: SpringerVerlag.

Kreijns, K. Kirschner, P. \& Jochems, W. (2003). Identifying the pitfalls for social interaction in computer-supported collaborative learning environments: A review of the research, Computers in Human Behavior, 19(3), 335-353.

Laurillard, D. (2002). Rethinking University Teaching: a conversational framework for the effective use of learning technologies, ( $2^{\text {nd }}$ ed.). London: Routledge.

Lehtinen, E., Hakkarainen, K., Lipponen, L., Rahikainen, M. \& Muukkonen, H. (1997). 
Computer Supported Collaborative Learning: A Review. Retrieved June 6, 2005, from http://www.comlab.hut.fi/opetus/205/etatehtava1.pdf

Lenning, O. \& Ebbers, L. (1999). The powerful potential of learning communities: Improving education for the future. Washington, DC: The George Washington University.

Lock, J. (2002). Laying the groundwork for the development of learning communities within online courses, Quarterly Review of Distance Education, 3(4), 395-408.

Lopez-Ortiz, B. \& Lin L. (2005). What Makes an Online Group Project Work? Students’ Perceptions before and after an Online Collaborative Problem/Project-Based Learning (PBL) Experience, International Journal of Instructional Technology and Distance Learning. Retrieved May 22, 2005, from http://www.itdl.org/Journal/Feb_05/article04.htm

Mason, R. \& Miller, W. (2000). Factors affecting students' satisfaction on a web course: The UK Open University, Australian Journal of Educational Technology, 16(2), 173-200. Retrieved June, 7, 2005 from http://www.ascilite.org.au/ajet/ajet16/mason.html Masters, K. \& Oberprieler, G. (2004). Encouraging equitable online participation through curriculum articulation, Computers \& Education, 42(4), 319-332.

McClure, B. (1998). Putting a New Spin on Groups: The Science of Chaos. Mahway, NJ: Lawrence Erlbaum Associates.

McGrath, J. \& Hollingshead, A. (1994). Groups interacting with technology: Ideas, evidence, issues, and an agenda. Thousand Oaks, CA: Sage.

McConnell, D. (2000) Implementing computer supported cooperative learning. London: Kogan Page.

McDonald, J. \& Gibson, C. (1998). Interpersonal dynamics and group development in computer conferencing, The American Journal of Distance Education, 12(1), 7-25.

Meyer, K. (2004). Evaluating Online Discussions: Four Different Frames of Analysis, Journal of Asynchronous Learning Networks, 8(2). Retrieved May, 14, 2005, from http://www.sloan-c.org/publications/jaln/v8n2/v8n2_meyer.asp_ 
Muirhead, B. (2004). Research Insights into Interactivity, International Journal of Instructional Technology and Distance Learning, 1(3). Retrieved June 6, 2005 from http://www.itdl.org/Journal/Mar_04/article05.htm

Northrup, P. (2001). A framework for designing interactivity into web-based instruction.

Educational Technology, 41(2), 31-39. Retrieved May 21, 2005, from http://cops.uwf.edu/itc/itc-research/Framework forOnline Interaction.pdf

Palloff, R. \& Pratt, K. (2001). Lessons from the Cyberspace classroom. San Francisco: John Wiley and Sons.

Pavitt, C. (1998). Small Group Communication: A Theoretical Approach, ( ${ }^{\text {rd }}$ ed.). Retrieved May 17, 2005, from http://www.udel.edu/communication/pavitt/bookindex.htm

Pena-Shaff, J. \& Nicholls, C. (2004). Analyzing student interactions and meaning construction in computer bulletin board discussions, Computers \& Education, 42(3), 243265.

Picciano, A. (1998). Developing an Asynchronous Course Model at a Large Urban University, Journal of Asynchronous Learning Network, 2(1) 1-14. Retrieved May 19, 2005, from http://www.aln.org/publications/jaln/v2n1/v2n1_picciano.asp

Quinsee, S. (2002). An analysis of the effectiveness of a threaded discussion forum to improve information management and encourage peer learning. Retrieved May 29, 2005, from http://www.ioe.ac.uk/schools/leid/oet/OET\%20html\%202001\%20essay\%2 Odocs/Quinsee_S.htm

Salmon, G. (2002). E-tivities: The key to active online learning. London: Kogan Page.

Salmon, G. (2002b). Approaches to researching teaching and learning online. In: Steeples, C. and Jones, C. (Eds.), Networked Learning: Perspectives and Issues. London: Springer-Verlag.

Salmon, G. (2003). E-Moderating: The key to teaching and learning online ( $2^{\text {nd }}$ ed). London: Taylor \& Francis.

Schrage, M. (2002). The Debriefing: John Seely Brown. Retrieved May 16, 2005, from 
http://www.wired.com/wired/archive/8.08/brown_pr.html

Song, L., Singleton, E., Hill, J. \& Koh, M. (2004). Improving Online Learning: Student Perceptions of Useful and Challenging Characteristics, Internet and Higher Education, 42(4), 59-70.

Stacey, E. (1999). Collaborative Learning in an Online Environment, Journal of Distance Education, 14(2). Retrieved June 7, 2005, from http://cade.icaap.org/vol14.2/stacey.html

Stemler, S. (2001). An overview of content analysis, Practical Assessment, Research \& Evaluation, 7(17). Retrieved May 29, 2005, from http://PAREonline.net/getvn.asp?v=7\&n=17

USD (2004). VoiceLink Overview: Telephone recording software. Retrieved July, 4 2003, from http://www.usdcorp.net/products/overview.asp

Vonderwell, S. (2003). An examination of asynchronous communication experiences and perspectives of students in an online course: A case study, The Internet and Higher Education, 6, 77-90.

Warkentin, M. Sayeed, L. \& Hightower, R. (1997). Virtual teams versus face-to- face teams: An exploratory study of a Web-based conference system, Decision Sciences. Retrieved May 17, 2005, from http://www.findarticles.com/p/articles/mi_qa3713/is_199710/ai_n875880 6/pg_2

Wenger, E. (1999). Communities of Practice: Learning, Meaning and Identity. Cambridge: Cambridge University Press.

Yin, R. (1994). Case study research: Design and methods (2nd ed.). Beverly Hills, CA: Sage Publishing. 
Table 1. Modified content analysis framework based on Bales’ (1950) IPA framework

\begin{tabular}{|l|}
\hline Categories \\
\hline Social emotional Area: Positive Reactions \\
\hline 1 Shows solidarity, raises other's status, gives help, reward \\
\hline 2 Shows tension release, jokes, laughs, shows satisfaction \\
\hline 3 Agrees, shows passive acceptance, understands, concurs, complies \\
\hline Task Area: Attempted Answers \\
\hline 4 Gives suggestion, direction, implying autonomy for other \\
\hline 4.1 Gives organisational suggestion or direction \\
\hline 4.2 Gives task suggestion or direction \\
\hline 5 Gives opinion, evaluation, analysis, express feeling, wish \\
\hline 5.1 Gives evaluation, analysis, peer review \\
\hline 5.2 Gives opinion, expresses feeling, wish \\
\hline 6 Gives orientation, information, repeats, clarifies, confirms \\
\hline 6.1 Gives personal information (positive social or emotional)* \\
\hline 6.2 Gives topic-related information* \\
\hline 6. 21 Gives non-referential topic-related information: make no reference to others' statements \\
\hline 6. 22 Gives referential topic-related information: make direct or indirect reference to others' statements \\
\hline 6.3 Gives technical information* \\
\hline Task Area: Questions \\
\hline 7 Asks for orientation, information, repetition, confirmation \\
\hline 7.1 Asks for technical information* or reports a technical problem \\
\hline 7.2 Asks for topic-related information* \\
\hline 7.21 Asks for non-referential topic-related information: make no reference to others' statements \\
\hline 7.22 Asks for referential topic-related information: make direct or indirect reference to others' statements \\
\hline 7.3 Asks for personal information (positive social or emotional)* \\
\hline 8 Asks for opinion, evaluation, analysis, expression of feeling \\
\hline 8.1 Asks for evaluation, analysis, peer review \\
\hline 8.2 Asks for opinion, feeling, wish \\
\hline 9 Asks for suggestion, direction, possible ways of action \\
\hline 9.1 Asks for organisational suggestion or direction \\
\hline 9.2 Asks for task suggestion or direction \\
\hline Social emotional Area: Negative Reactions \\
\hline 10 Disagrees, shows passive rejection, formality, withholds help \\
\hline 11 Shows tension, asks for help, withdraws out of field \\
\hline 12 Shows antagonism, deflates other's status, defends or asserts self \\
\hline
\end{tabular}

* Categories are additions to the original Interaction Process Analysis by Chou (2002)

Categories in italics and blue are additions to the original Interaction Process Analysis by the principal investigator. 
Table 2: Student, lecturer and total units categorised under categories 1-12 of the modified Bales IPA within each module

\begin{tabular}{|c|c|c|c|c|c|c|c|c|c|c|c|c|}
\hline & \multicolumn{3}{|c|}{ INM341 } & \multicolumn{3}{c|}{ INM301 } & \multicolumn{3}{c|}{ INM303 } \\
\hline $\begin{array}{c}\text { Framework } \\
\text { Category }\end{array}$ & $\begin{array}{c}\text { Student } \\
\text { total }\end{array}$ & $\begin{array}{c}\text { Lecturer } \\
\text { total }\end{array}$ & $\begin{array}{c}\text { Category } \\
\text { Total }\end{array}$ & $\begin{array}{c}\text { Student } \\
\text { total }\end{array}$ & $\begin{array}{c}\text { Lecturer } \\
\text { total }\end{array}$ & $\begin{array}{c}\text { Category } \\
\text { Total }\end{array}$ & $\begin{array}{c}\text { Student } \\
\text { total }\end{array}$ & $\begin{array}{c}\text { Lecturer } \\
\text { total }\end{array}$ & $\begin{array}{c}\text { Category } \\
\text { Total }\end{array}$ & $\begin{array}{c}\text { Student } \\
\text { total }\end{array}$ & $\begin{array}{c}\text { Lecturer } \\
\text { total }\end{array}$ & $\begin{array}{c}\text { Category } \\
\text { Total }\end{array}$ \\
\hline $\mathbf{1}$ & 36 & 0 & 36 & 11 & 0 & 11 & 58 & 3 & 61 & 6 & 11 & 17 \\
\hline $\mathbf{2}$ & 0 & 0 & 0 & 0 & 0 & 0 & 7 & 0 & 7 & 1 & 0 & 1 \\
\hline $\mathbf{3}$ & 6 & 0 & 6 & 1 & 0 & 1 & 13 & 2 & 15 & 1 & 0 & 1 \\
\hline $\mathbf{4}$ & 13 & 0 & 13 & 1 & 0 & 1 & 38 & 0 & 38 & 2 & 1 & 3 \\
\hline $\mathbf{5}$ & 65 & 0 & 65 & 5 & 0 & 5 & 61 & 4 & 65 & 2 & 1 & 3 \\
\hline $\mathbf{6}$ & 67 & 0 & 67 & 61 & 0 & 61 & 272 & 4 & 276 & 6 & 0 & 6 \\
\hline $\mathbf{7}$ & 9 & 0 & 9 & 3 & 0 & 3 & 18 & 0 & 18 & 2 & 1 & 3 \\
\hline $\mathbf{8}$ & 0 & 0 & 0 & 0 & 0 & 0 & 6 & 0 & 6 & 2 & 0 & 2 \\
\hline $\mathbf{9}$ & 4 & 0 & 4 & 3 & 0 & 3 & 9 & 0 & 9 & 4 & 0 & 4 \\
\hline $\mathbf{1 0}$ & 2 & 0 & 2 & 0 & 0 & 0 & 3 & 0 & 3 & 0 & 0 & 0 \\
\hline $\mathbf{1 1}$ & 2 & 0 & 2 & 0 & 0 & 0 & 4 & 0 & 4 & 0 & 0 & 0 \\
\hline $\mathbf{1 2}$ & 1 & 0 & 1 & 0 & 0 & 0 & 0 & 0 & 0 & 0 & 0 & 0 \\
\hline
\end{tabular}

Table 3: Student, lecturer and total units categorised under all sub-categories of the modified Bales IPA within each module

\begin{tabular}{|c|c|c|c|c|c|c|c|c|c|c|c|c|}
\hline & \multicolumn{3}{|c|}{ INM341 } & \multicolumn{3}{c|}{ INM301 } & \multicolumn{3}{c|}{ INM303 } & \multicolumn{3}{c|}{ INM302 } \\
\hline $\begin{array}{c}\text { Framework } \\
\text { Category }\end{array}$ & $\begin{array}{c}\text { Student } \\
\text { total }\end{array}$ & $\begin{array}{c}\text { Lecturer } \\
\text { total }\end{array}$ & $\begin{array}{c}\text { Category } \\
\text { Total }\end{array}$ & $\begin{array}{c}\text { Student } \\
\text { total }\end{array}$ & $\begin{array}{c}\text { Lecturer } \\
\text { total }\end{array}$ & $\begin{array}{c}\text { Category } \\
\text { Total }\end{array}$ & $\begin{array}{c}\text { Student } \\
\text { total }\end{array}$ & $\begin{array}{c}\text { Lecturer } \\
\text { total }\end{array}$ & $\begin{array}{c}\text { Category } \\
\text { Total }\end{array}$ & $\begin{array}{c}\text { Student } \\
\text { total }\end{array}$ & $\begin{array}{c}\text { Lecturer } \\
\text { total }\end{array}$ & $\begin{array}{c}\text { Category } \\
\text { Total }\end{array}$ \\
\hline $\mathbf{4 . 1}$ & 9 & 0 & 9 & 1 & 0 & 1 & 6 & 0 & 6 & 1 & 1 & 2 \\
\hline $\mathbf{4 . 2}$ & 4 & 0 & 4 & 0 & 0 & 0 & 32 & 0 & 32 & 1 & 0 & 1 \\
\hline $\mathbf{5 . 1}$ & 0 & 0 & 0 & 0 & 0 & 0 & 36 & 4 & 40 & 0 & 0 & 0 \\
\hline $\mathbf{5 . 2}$ & 65 & 0 & 65 & 5 & 0 & 5 & 25 & 0 & 25 & 6 & 0 & 6 \\
\hline $\mathbf{6 . 1}$ & 0 & 0 & 0 & 0 & 0 & 0 & 0 & 0 & 0 & 0 & 0 & 0 \\
\hline $\mathbf{6 . 2}$ & 67 & 0 & 67 & 61 & 0 & 61 & 268 & 0 & 272 & 21 & 3 & 24 \\
\hline $\mathbf{6 . 2 1}$ & 51 & 0 & 51 & 56 & 0 & 56 & 239 & 0 & 239 & 16 & 2 & 18 \\
\hline $\mathbf{6 . 2 2}$ & 16 & 0 & 16 & 5 & 0 & 5 & 29 & 4 & 33 & 5 & 1 & 6 \\
\hline $\mathbf{6 . 3}$ & 0 & 0 & 0 & 0 & 0 & 0 & 4 & 0 & 4 & 3 & 5 & 8 \\
\hline $\mathbf{7 . 1}$ & 2 & 0 & 2 & 2 & 0 & 2 & 8 & 0 & 8 & 1 & 0 & 1 \\
\hline $\mathbf{7 . 2}$ & 7 & 0 & 7 & 1 & 0 & 1 & 10 & 0 & 10 & 0 & 1 & 1 \\
\hline $\mathbf{7 . 2 1}$ & 3 & 0 & 3 & 1 & 0 & 1 & 8 & 0 & 8 & 0 & 1 & 1 \\
\hline $\mathbf{7 . 2 2}$ & 4 & 0 & 4 & 0 & 0 & 0 & 2 & 0 & 2 & 0 & 0 & 0 \\
\hline $\mathbf{7 . 3}$ & 0 & 0 & 0 & 0 & 0 & 0 & 0 & 0 & 0 & 1 & 0 & 1 \\
\hline $\mathbf{8 . 1}$ & 0 & 0 & 0 & 0 & 0 & 0 & 5 & 0 & 5 & 2 & 0 & 2 \\
\hline $\mathbf{8 . 2}$ & 0 & 0 & 0 & 0 & 0 & 0 & 1 & 0 & 1 & 0 & 0 & 0 \\
\hline $\mathbf{9 . 1}$ & 2 & 0 & 2 & 1 & 0 & 1 & 0 & 0 & 0 & 4 & 0 & 4 \\
\hline $\mathbf{9 . 2}$ & 2 & 0 & 2 & 2 & 0 & 2 & 9 & 0 & 9 & 0 & 0 & 0 \\
\hline
\end{tabular}


Table 4: Summary of findings

\begin{tabular}{|c|c|}
\hline Theme & Summary \\
\hline $\begin{array}{l}\text { Enjoyment and } \\
\text { concerns in online } \\
\text { groups }\end{array}$ & $\begin{array}{l}\text { - Working in online groups is a positive experience for most students. } \\
\text { - Some students preferred not to work in groups if given the choice. } \\
\text { - Group members not participating on the discussion board and not contributing equally towards the completion of group } \\
\text { tasks were the most prominent concerns. } \\
\text { - Finding time to contribute towards group work and discussions was an issue for many part-time students. }\end{array}$ \\
\hline $\begin{array}{l}\text { Perceived purpose } \\
\text { of the } \\
\text { asynchronous } \\
\text { discussion board in } \\
\text { group work }\end{array}$ & $\begin{array}{l}\text { - The discussion board was seen as a viable alternative to face-to-face meetings and the most convenient way of contacting } \\
\text { group members. } \\
\text { - Most preferred having the option to use the discussion board, e-mail and face-to-face meetings. } \\
\text { - Some students only used the discussion board to post their final document if required by the group task. }\end{array}$ \\
\hline $\begin{array}{l}\text { Motivation to use } \\
\text { the asynchronous } \\
\text { discussion board } \\
\text { for group work }\end{array}$ & $\begin{array}{l}\text { - Some students were less likely to use the discussion board if the whole group could meet face-to-face. } \\
\text { - Students identified lack of enthusiasm to use technology, differences over the actual task and that preference was given to } \\
\text { assessed coursework to explain the non-collaboration in online groups. }\end{array}$ \\
\hline $\begin{array}{l}\text { Usefulness, } \\
\text { benefits and } \\
\text { challenges of using } \\
\text { the asynchronous } \\
\text { discussion board } \\
\text { for group work. }\end{array}$ & $\begin{array}{l}\text { - Most students found the discussion board useful for group work, particularly when they could not meet face-to-face. } \\
\text { - Benefits were the ability to share ideas, experiences and resources and the ability to conduct group work despite physical } \\
\text { separation } \\
\text { - Some thought the discussion board had improved their learning due to the ability to reflect on messages and had advanced } \\
\text { their communication skills. } \\
\text { - Some found the discussion board to be impersonal and intimidating. } \\
\text { - Sending large attachments was considered by some students as easier through e-mail, and other students felt more } \\
\text { comfortable using e-mail to discuss problems in confidence. } \\
\text { - The challenges experienced in using the discussion board for group work varied among students and some indicated that } \\
\text { they experienced no challenges at all. } \\
\text { - Time delays before replies was the most commonly cited challenge. } \\
\text { - Students reported experiencing anxiety over posting messages and misunderstanding due to lack of visual cues. } \\
\text { - Information Overload was identified as a challenge linked to the technological limitations of the discussion board in that } \\
\text { deleting, updating, organising and searching through messages was not possible. } \\
\text { - Technological problems prevented some students from accessing and using the discussion board. }\end{array}$ \\
\hline $\begin{array}{l}\text { Relative } \\
\text { importance } \\
\text { attributed to face- } \\
\text { to-face meetings in } \\
\text { online group work }\end{array}$ & $\begin{array}{l}\text { - Most students felt the need to meet face-to-face during group work. } \\
\text { - Students felt that bonding with group members and trying to explain complex ideas was easier face-to-face. } \\
\text { - Face-to-face meetings were perceived as particularly useful at the beginning of group tasks to make initial task decisions } \\
\text { and towards the end to compile work for submission or to rehearse the group presentation. }\end{array}$ \\
\hline $\begin{array}{l}\text { Perception of } \\
\text { discussion in } \\
\text { online group work }\end{array}$ & $\begin{array}{l}\text { - Students found it easier to discuss issues in smaller groups of three or four students. } \\
\text { - Students thought discussion was easier on the group discussion board than the general discussion area of each module } \\
\text { - Students recognised the value of having 'conversations' recorded for future reference and reflection. }\end{array}$ \\
\hline $\begin{array}{l}\text { Role of the } \\
\text { lecturer in online } \\
\text { group work }\end{array}$ & $\begin{array}{l}\text { - Lecturer presence in online groups was seen as important by most students. } \\
\text { - Many students thought lecturers should monitor and contribute to the discussion board and provide motivation. } \\
\text { - Attitudes varied with regard to the type of input and form of encouragement students felt lecturers should provide. } \\
\text { - Most students thought lecturers should intervene in online groups to clarify coursework requirements. } \\
\text { - Many students felt that lecturers should provide clarification on progress and correct inaccurate student contributions. } \\
\text { - Direction in the form of information resources, subject knowledge and discussion initiation was considered helpful and } \\
\text { some students thought lecturers should also address problems with technology, encourage those not participating and } \\
\text { mediate disagreements on the discussion board. } \\
\text { - Only a few students felt lecturers should allocate group roles and responsibilities and some students commented that } \\
\text { lecturers should not dominate discussions or censor material. } \\
\text { - Lecturers variably contributed encouragement, opinion, topic-related information and to a lesser extent, } \\
\text { agreement, task suggestions and requests for topic-related information. } \\
\text { - Lecturers posted topic-related information in reference to other group members statements and provided } \\
\text { analysis on documents submitted to the discussion board. } \\
\text { - Some students felt that the lecturer input did not make a difference to the group due to the peer interaction } \\
\text { - Alleady taking place. } \\
\text { interacted and completed group tasks without any lecturer input on the discussion board and students provided } \\
\text { more units than lecturers in all groups analysed. } \\
\text { - Students stated that student feedback on the discussion board during group work was more important than } \\
\text { lecturer feedback. }\end{array}$ \\
\hline $\begin{array}{l}\text { Process of } \\
\text { conducting online } \\
\text { group work }\end{array}$ & $\begin{array}{l}\text { - Full-time students tended to post more messages than part-time students. } \\
\text { - Most students stated that there was no established hierarchy in their online groups, roles were assumed and not assigned and } \\
\text { that they did not have a leader. } \\
\text { - Some students thought an online leader would be beneficial if they ensured equality, but not if they dominated the group }\end{array}$ \\
\hline
\end{tabular}




\begin{tabular}{|c|c|}
\hline Theme & Summary \\
\hline & $\begin{array}{l}\text { - Matput, whilst other students experienced dominating learners as a concern on the discussion board. } \\
\text { - Most students did not establish any ground rules on how, when or how often they were going to use the technology for } \\
\text { group work. } \\
\text { - Students usually assumed group members would view the group discussion board regularly and did not always experience } \\
\text { the feeling of security through expectations on how to contribute. }\end{array}$ \\
\hline $\begin{array}{l}\text { Factors } \\
\text { contributing to the } \\
\text { success of online } \\
\text { group work }\end{array}$ & $\begin{array}{l}\text { - Active participation was regarded by students as the most important factor influencing the success of online groups } \\
\text { - Most students did not find the discussion board itself was enough to ensure collaboration in groups } \\
\text { - An atmosphere of trust and respect, shared objectives and being supportive to other group members enabled many students } \\
\text { to overcome barriers to progress. } \\
\text { - Group working skills, such as decision-making, consensus building, and dealing with conflict were also strongly factored by } \\
\text { many students. } \\
\text { - Smaller groups were also thought to facilitate equal participation on the discussion board and were considered important for } \\
\text { the success of online groups. } \\
\text { - Students attributed importance to being familiar with other group members in order to communicate effectively and reduce } \\
\text { misunderstanding on the discussion board. Students felt it was more important to be familiar with group members than to } \\
\text { - work face-to-face and it was better to like group members than to be familiar with them. } \\
\text { - Students also recognised that group member confidence in using the discussion board and the technical functioning of the } \\
\text { - The nature of the group task seemed to influence how motivated students were to participate, the amount of academic } \\
\text { discussion on the discussion board and whether participating students collaborated or cooperated. }\end{array}$ \\
\hline
\end{tabular}

